\title{
Inventarisasi dan Identifikasi Objek Daya Tarik Wisata dalam Perencanaan Pariwisata Wakatobi
}

\section{Inventory and Identification of Tourism Attractions in Wakatobi Tourism Planning}

\author{
Ray March Syahadat ${ }^{1^{*}}$ \\ ${ }^{1}$ Program Doktor Kajian Pariwisata, Universitas Gadjah Mada, Yogyakarta, Indonesia; \\ *Penulis korespondensi.e-mail: ray.march.syahadat@mail.ugm.ac.id \\ (Diterima: 25 Juli 2021; Disetujui: 7 November 2021)
}

\begin{abstract}
Wakatobi's prestige has recently dimmed compared to other similar tourism areas in Indonesia. Carrying the theme of a real underwater paradise in the center of the world's coral triangle, it is sometimes slipped by local people as hell on land. The cause of this phenomenon is the lack of understanding on the power of objects, especially objects in terrestrial areas, whereas tourists who come to Wakatobi spend time not only under the sea, but also more time on land. The aims of this study were to provide information about tourist attractions in Wakatobi in terms of originality, authenticity, uniqueness, diversity, and beauty. Data and information were collected by means of document searches and interviews with key informants. The result showed that Wakatobi cannot be viewed as just one place but the four major islands that compose it. In general, natural, historical, and cultural tourism are spread throughout the islands in Wakatobi. Icons that can be highlighted as strengths of each of the four main islands include dolphin migration attraction in Wangi-Wangi, historical and cultural heritage attractions, especially the Lariangi Dance in Kaledupa, underwater beauty in Tomia, and geological landscape of the rock garden in Binongko. All tourist attractions in Wakatobi shall be connected with the strengthening of infrastructure, which currently seems to be concentrated in the capital only.
\end{abstract}

Keywords: dolphin migration, geological landscape, Lariangi Dance, tourist icon, underwater beauty

\begin{abstract}
ABSTRAK
Pamor Wakatobi belakangan dirasa meredup, bahkan kalah dengan wisata lain yang sejenis di Indonesia. Mengusung tema surga nyata bawah laut di pusat segitiga karang dunia kadang dipelesetkan oleh masyarakat setempat sebagai neraka di daratan. Penyebab fenomena ini yaitu kurang pemahaman kekuatan objek khususnya objek yang berada di wilayah terestrial, padahal wisatawan yang datang ke Wakatobi tidak hanya berada di bawah laut tetapi juga menghabiskan lebih banyak waktu di daratan. Studi ini bertujuan untuk memberikan informasi mengenai daya tarik wisata di Wakatobi yang dilihat dari orisinalitas, autentisitas, keunikan, keragaman, dan keindahan. Data dan informasi dikumpulkan dengan cara penelusuran dokumen dan wawancara kepada informan kunci. Didapatkan hasil bahwa Wakatobi tidak dapat dipandang hanya sebagai satu tempat tetapi empat pulau besar utama yang menyusunnya. Secara umum, wisata alam, sejarah, dan budaya tersebar di seluruh pulau-pulau di Wakatobi. Ikon yang bisa ditonjolkan sebagai kekuatan masingmasing empat pulau utama antara lain atraksi migrasi lumba-lumba di Wangi-Wangi, atraksi peninggalan sejarah dan budaya khususnya Tari Lariangi di Kaledupa, keindahan bawah laut di
\end{abstract}


Tomia, dan lanskap geologi taman batu di Binongko. Seluruh daya tarik wisata di Wakatobi perlu dikoneksikan dengan penguatan infrastruktur yang saat ini masih terpusat di ibukota saja.

Kata kunci: ikon wisata, keindahan bawah laut, lanskap geologi, migrasi lumba-lumba, Tari Lariangi

\section{PENDAHULUAN}

Wakatobi merupakan salah satu kabupaten yang berada di Provinsi Sulawesi Tenggara. Berbeda dengan kabupaten/kota di Sulawesi Tenggara lainnya, kabupaten ini memiliki karakter utama sebagai daerah wisata. Melalui Peraturan Pemerintah Nomor 50 Tahun 2011 tentang Rencana Induk Pembangunan Pariwisata Nasional, ditetapkan Wakatobi sebagai sebagai salah satu destinasi pariwisata prioritas. Pada tahun 2016 melalui Peraturan Presiden Nomor 3 Tahun 2016 selanjutnya Wakatobi ditetapkan sebagai 10 Kawasan Strategis Pariwisata Nasional. Tujuan dari program tersebut untuk meningkatkan devisa negara dan meningkatkan pendapatan serta pemberdayaan masyarakat.

Grand Design Pembangunan Daerah Kabupaten Wakatobi 2017 sampai 2021 telah dirumuskan dengan mengusung visi menjadi kabupaten maritim yang sejahtera dan berdaya saing. Adapun misinya antara lain: 1) mengembangkan kualitas SDM, 2) membangun ekonomi kemaritiman yang berkelanjutan dan berwawasan lingkungan, 3) membangun infrastruktur publik, 4) mengembangkan pemerintahan yang inovatif dan partisipatif serta pelayanan publik yang berkualitas berbasis teknologi informasi, dan 5) mengembangkan kolaborasi regional dan internasional. Visi pembangunan kepariwisataan daerah Kabupaten Wakatobi juga telah ditetapkan yaitu "Terwujudnya Wakatobi sebagai Destinasi Ekowisata Berkelas Dunia dan Berbasis Masyarakat". Melalui dokumen Rencana Induk Pengembangan Pariwisata Daerah (RIPPARDA) Kabupaten Wakatobi, dipetakan wilayah-wilayah destinasi yang terbagi menjadi tiga kelompok utama (4 Destinasi Pariwisata Kabupaten, 7 Kawasan Strategis Pariwisata Daerah, dan 20 Kawasan Pengembangan Pariwisata Daerah)

Sejauh ini Wakatobi tengah gencar membangun daerah untuk mendukung pariwisatanya. Kegiatan perencanaan telah dilakukan mulai dari penyusunan Rencana Tata Ruang Wilayah (RTRW), Strategi Penyelenggaraan Kawasan Permukiman (SPKP), hingga Rencana Pembangunan Industri Provinsi (RPIP) yang memiliki substansi penyusunan masterplan kawasan, konsep desain kawasan dan bangunan (3D), sampai dengan rencana aksi program. Meskipun kegiatan perencanaan telah sejauh ini, pamor Wakatobi belum naik dan bisa dikatakan kalah dengan daerah lain. World Bank (2017) dalam kajiannya menilai Wakatobi "too far and too small". Bahkan dalam laporan tersebut dikatakan secara tegas bahwa Raja Ampat adalah opsi terbaik. Hal ini menjadi tantangan serius untuk Wakatobi karena dari 10 Kawasan Strategis Pariwisata Nasional, beberapa di antaranya memiliki karakter yang sama sebagai kawasan wisata bahari.

Fenomena ini diduga karena kurangnya pemahaman dalam memahami daya tarik wisata di Wakatobi sehingga terkesan kalah pamor dibanding daerah lain. Daya tarik wisata terkait dengan empat hal yaitu orisinalitas, autentisitas, keunikan, dan keragaman (Damanik \& Weber, 2006). Orisinalitas merupakan keaslian atau kemurnian. Autentisitas mengacu pada keaslian nilai alamiah. Keunikan yaitu kekhasan pada suatu objek. Selanjutnya keragaman yaitu perbedaan antar objek. Terkadang orisinalitas dan autentisitas sering sulit dibedakan. Autentisitas lebih sering dikaitkan dengan eksotisme sebagai daya tarik wisata, sedangkan orisinalitas merupakan kemurnian tanpa pengaruh dari luar (Harsana et al., 2018). Selain empat hal tersebut, ada pula nilai keindahan yang merupakan bagian dari ilmu estetika dan bersifat kualitatif (Baumgarten, 1983; Harris \& Dines, 2006).

Selama ini Wakatobi hanya dikenal dengan adanya wisata bawah laut. Padahal, wisatawan sejatinya tidak hanya berada di bawah laut. Lelucon yang sering diungkapkan oleh masyarakat yakni surga bawah laut namun neraka di daratan, nampaknya dapat menggambarkan kondisi Wakatobi saat ini. Padahal sesungguhnya Wakatobi 
juga memiliki objek wisata daratan namun nampaknya belum dimaknai lebih dalam sebagai kekuatan. Fenomena ini menjadikan Wakatobi tidak punya pamor yang kuat jika dibandingkan destinasi sejenis. Untuk itu dirasa perlu adanya studi yang lebih mendalam untuk memahami kekuatan objek yang ada di Wakatobi sehingga dapat dimanfaatkan dalam kegiatan perencanaan dan perancangan yang mampu memperkuat brand, menciptakan sense of place, dan tentunya mencapai visi kepariwisataanya. Artikel ini bertujuan untuk menginventarisasi dan mengidentifikasi daya tarik wisata dilihat dari orisinalitas, autentisitas, keunikan, keragaman, dan keindahan.

\section{METODOLOGI}

Data dikumpulkan dengan melakukan penelusuran dokumen dan wawancara. Pendekatan ini mengacu pada pendekatan yang pernah dilakukan oleh Bala \& Verma (2018) serta Killian \& McManus (2015). Kegiatan penelusuran dokumen dikhususkan inventarisasi objek. Dokumen-dokumen yang digunakan mengacu pada artikel yang telah dipublikasikan pada jurnal ilmiah, dokumen perencanaan, produk hukum, dan dokumen-dokumen lain yang dianggap relevan. Selanjutnya, kegiatan wawancara dilaksanakan untuk melengkapi hasil inventarisasi dan juga sebagai konfirmasi agar menghindari subjektivitas dan kesalahan informasi. Kegiatan wawancara dilakukan secara online kepada Pemerintah Daerah Wakatobi, Balai Taman Nasional, organisasi, dan juga tokoh masyarakat pada masing-masing empat pulau besar. Hasilnya kemudian dikelompokkan berdasarkan jenisnya yakni objek daya tarik wisata alam, sejarah, dan budaya lalu dianalisis secara deskriptif. Analisis deskriptif difokuskan untuk menggali nilai orisinalitas, autentisitas, keunikan, keragaman, dan keindahan yang mengacu pada Baumgarten (1983), Damanik \& Weber (2006), Harris \& Dines (2006), serta Harsana et al. (2018). Adapun kriterianya dapat dilihat pada Tabel 1.

\section{HASIL DAN PEMBAHASAN}

Wakatobi dulunya eksis dengan nama Kepulauan Tukang Besi atau Pande Wesi. Sejak zaman dulu Wakatobi sudah eksis karena merupakan bagian dari Kerajaan dan Kesultanan Buton (Zahari, 1977). Bahkan persenjataan Kerajaan dan Kesultanan Buton disuplai dari Pulau Binongko dan masih dapat ditemui hingga saat ini. Berdasarkan Undang-Undang Nomor 29 Tahun 2003 tentang Pembentukan Kabupaten Bombana, Kabupaten Wakatobi, dan Kabupaten Kolaka Utara di Provinsi Sulawesi Tenggara. Wakatobi menjadi daerah otonom baru yang memisahkan diri dari Kabupaten Buton. Nama Wakatobi sendiri merupakan singkatan dari empat pulau utama yang menyusunnya yaitu Wangi-Wangi, Kaledupa, Tomia dan Binongko. Oleh karena itu, ketika berbicara mengenai Wakatobi, sesungguhnya tidak semata-mata membahas satu daerah tetapi empat daerah. Hal ini disebabkan setiap daerah memiliki karakter yang sangat berbeda satu dengan yang lainnya baik alam, sejarah, maupun budaya.

Tabel 1. Kriteria orisinalitas, autentisitas, keunikan, keragaman, dan keindahan.

\begin{tabular}{|c|c|c|}
\hline No. & Variabel & Kriteria \\
\hline 1 & Orisinalitas & $\begin{array}{l}\text { Objek asli namun masih } \\
\text { dapat ditemukan di tempat } \\
\text { lain. }\end{array}$ \\
\hline 2 & Autentisitas & $\begin{array}{l}\text { Objek asli dan alami namun } \\
\text { hanya terdapat di tempat } \\
\text { tersebut. }\end{array}$ \\
\hline 3 & Keunikan & $\begin{array}{l}\text { Objek memiliki ciri khas } \\
\text { yang menunjukkan dirinya } \\
\text { berbeda dari objek lainnya. }\end{array}$ \\
\hline 4 & Keragaman & $\begin{array}{l}\text { Objek tidak bersifat tunggal } \\
\text { dan semakin majemuk } \\
\text { semakin tinggi nilainya. }\end{array}$ \\
\hline 5 & Keindahan & $\begin{array}{l}\text { Objek memiliki kejelasan } \\
\text { yang dapat dinikmati } \\
\text { pancaindra tanpa adanya } \\
\text { gangguan yang berarti dan } \\
\text { menimbulkan kesenangan. }\end{array}$ \\
\hline
\end{tabular}

Empat pulau utama ini memiliki asal muasal nama yang juga berbeda-beda karena perbedaan sejarah dan linguistik dari keempat pulau. Nama Wangi-Wangi berdasarkan tradisi lisan masyarakat setempat berarti beraroma wangi/harum karena dahulu masyarakat menjemur rempah-rempah yang tertiup oleh angin. Kaledupa bermakna daratan 
beraroma dupa. Ciri Hinduisme memang banyak ditemui pada budaya yang berlaku di pulau ini, misalnya pada Tarian Lariangi yang sakral bagi masyarakat Kaledupa (Sofian, 2018). Diduga aroma dupa yang menjadi asal nama Keledupa tersebut merupakan bagian dari ritual zaman dulu yang sudah ditinggalkan. Terlebih jejak hubungan Buton dan Majapahit tercatat pada Kitab Negarakertagama oleh Mpu Prapanca (Adji, 2013). Selanjutnya, Pulau Tomia berasal dari dua suku kata yaitu to yang bermakna itu dan mia yang bermakna orang. Jadi Tomia kurang lebih bermakna itu orang. Konon dahulu saat pulau ini ditemukan terlihat dari kejauhan seperti ada seseorang berdiri di pulau tersebut sehingga menyahutlah orang yang melihatnya "itu orang!". Terakhir, pulau besar paling selatan di Wakatobi yakni Binongko, bermakna kepala kapal. Tidak mengherankan karena orang Binongko memang sangat terkenal dalam pembuatan kapal dan piawai dalam mengarungi samudera (Hamid, 2015).

Sebelum menjadi kabupaten, melalui Surat Keputusan Menteri Kehutanan RI Nomor 393/Kpts-II/1996 tentang Taman Nasional Laut Wakatobi, Wakatobi ditetapkan sebagai taman nasional. Oleh karena itu karakter Kabupaten Wakatobi sangat berbeda karena berdiri di atas taman nasional. Geliat wisata di Wakatobi sudah terjadi sejak lama namun hanya dilakukan oleh masyarakat lokal. Dahulu Pulau Hoga yang berada di seberang Pulau Kaledupa berdasarkan tradisi lisan, sudah sering dilaksanakan kegiatan rekreasi oleh pihak Barata Kahedupa. Informasi yang diperoleh dari Al Dilwan et al. (2019), pariwisata Wakatobi dimulai ketika Wakatobi Dive Resort (WDR) di Pulau Tolandono dan Operation Wallacea di Pulau Hoga memulai usaha wisata pada pertengahan dekade 1990-an. Kedua usaha tersebut menawarkan atraksi diving dan snorkeling.

Daya tarik wisata di Wakatobi memang unggul di dunia akuatik yang tidak diherankan karena 97\% wilayahnya memang berupa perairan. Meskipun demikian, daya tarik sejarah dan budaya di wilayah terestrial juga dimiliki Wakatobi meskipun sejauh ini nampaknya belum teroptimalkan. Terdapat 11 subetnik yang mendiami Wakatobi. Masing-masing etnis tersebut memiliki kebudayaan yang berbeda.
Peninggalan sejarah yang banyak ditemukan di daratan Wakatobi yaitu benteng-benteng era zaman Kerajaan dan Kesultanan Buton.

\section{Objek Daya Tarik Wisata Alam}

Taman Nasional Wakatobi memiliki keanekaragaman hayati bawah laut yang luar biasa. Hal ini dibuktikan dengan adanya 750 spesies karang, 942 spesies ikan, dan menjadi homebase beberapa spesies penyu. Taman Nasional Wakatobi pada tahun 2012 juga telah ditetapkan UNESCO sebagai salah satu dari 19 cagar biosfer yang ada di Indonesia (Diyati \& Rani, 2018; Portal Informasi Indonesia, 2020; Munawaroh et al., 2018; Ramaddin et al., 2019; Yulius et al., 2015).

Pamor Wakatobi pada awalnya memang tumbuh dari daya tarik bawah laut. Sebelum dieksplorasi lebih lanjut, jumlah dive site yang menjadi daya tarik wisata di Wakatobi hanya ada di beberapa titik saja. Salah satu yang menjadi favorit di awal eksistensi wisata bawah laut Wakatobi adalah Situs Pinnacle. Secara harfiah situs ini bermakna puncak karena struktur terumbu karangnya seperti kumpulan gunung. Situs Pinnacle yang berada di Pulau Hoga bahkan menjadi keunikan tersendiri karena terdapat gerombolan ikan barakuda. Oleh karena itu, kegiatan wisata di situs ini menimbulkan sensasi yang berbeda karena menyelam dalam pusaran ikan. Pada perairan Pulau Hoga ini juga dapat ditemui kuda laut pygmy yang merupakan spesies kuda laut terkecil di dunia yang hidup di koral kipas. Kuda laut ini juga hanya dapat ditemukan di daerah barat dan tengah Samudera Pasifik (Wakatobi Tourism Authority, 2019).

Pada tahun 2020 berdasarkan data dari Balai Taman Nasional Wakatobi terdapat 86 dive site. Kemudian, sejauh ini terdapat 12 dive site yang diidentifikasi sebagai potensi baru. Berdasarkan informasi dari Dinas Pariwisata Kabupaten Wakatobi, dunia bawah laut masih menjadi daya tarik utama dengan menjadikan jumlah spesies terumbu karang sebagai kata kuncinya. Sebagai komparasi, jumlah spesies terumbu karang di Wakatobi yang teridentifikasi terdapat sebanyak 750 spesies, sedangkan diving center dunia seperti di Karibia dan Laut Merah masing-masing hanya memiliki 50 dan 300 spesies dari 850 total spesies terumbu karang yang ada di dunia. Luas area 
terumbu karang yang ada di Wakatobi sebesar $118,000,000$ ha dan terdapat atol tunggal terpanjang di dunia yakni Kaledupa Reef sepanjang $48 \mathrm{~km}$. Keindahan bawah laut di seluruh wilayah Wakatobi dapat dinikmati dengan cara diving maupun snorkeling (Dinas Pariwisata Pemda Wakatobi, 2012).

Pulau Tomia beserta pulau satelitnya memiliki keindahan bawah laut yang menakjubkan (Arianto, 2011; Darman et al., 2020; Dinas Pariwisata Pemda Wakatobi, 2012). Dive sites paling banyak ditemukan perairan di pulau ini. [Gambar 1] Terdapat setidaknya 40 dive sites yang sudah dikenalkan kepada wisatawan. Dive sites yang ada bukan hanya menyajikan keindahan terumbu karang tetapi juga penyu, ikan, dan kapal peninggalan Jepang sebagai arkeologi bawah laut. Dive site bernama Marimabok merupakan salah satu yang terkenal (Arianto, 2011). Kemudian ada pula dive site bernama The Zoo yang menawarkan atraksi diving pada malam hari untuk melihat hewan-hewan nokturnal. Atraksi migrasi lumbalumba di perairan Pulau Kapota pada pukul 4 sampai 5 pagi belakangan juga menjadi daya tarik (Wakatobi Tourism Authority, 2019). Salah satu penyebabnya karena kemudahan untuk menikmatinya. Pengunjung hanya butuh naik kapal dan diantarkan ke jalur migrasi lumba-lumba untuk menontonnya [Gambar 2].

Titik tertinggi Kepulauan Wakatobi berada di Pulau Kaledupa tepatnya di Desa Pajam. Menurut laporan masyarakat, sudah mulai ada aktivitas wisata ke titik tertinggi ini namun belum diorganisasikan. Keunikan tempat ini yaitu dapat dilihatnya seluruh gugusan pulau yang ada di Wakatobi. Daratan Kaledupa merupakan daratan paling subur di antara seluruh pulau di Wakatobi sehingga makna orisinalitas terlihat di sini. Tidak mengherankan bahwa potensi agrowisata juga ada di tempat ini meskipun belum dilirik secara penuh (Lukman et al., 2019; Dinas Penanaman Modal dan Pelayanan Terpadu Satu Pintu Kabupaten Wakatobi, 2020). Suburnya daratan mengakibatkan adanya aliran energi yang mencuci permukaan tanah berakhir di pesisir. Tak heran proses ini mengakibatkan munculnya ekosistem mangrove yang didominasi tumbuhan
Rhizopora sp., Avicennia spp, dan Soneratia spp. yang luasnya sangat besar meskipun tidak ada daerah aliran sungai di pulau ini. Bagian utara pulau memiliki karakter mangrove yang dapat dilakukan penjelajahan dengan berjalan kaki sedangkan bagian selatan memiliki karakter yang hanya dapat dijelajahi dengan menggunakan perahu. Mangrove di Tanjung Sombano yang terletak di utara Pulau Kaledupa menyimpan potensi keindahan alam yang luar biasa karena terdapat danau air asin yang disakralkan masyarakat. Danau ini juga merupakan habitat beberapa satwa bahkan di antaranya adalah satwa endemik (Fisu et al., 2020; Dinas Pariwisata Pemda Wakatobi, 2012).
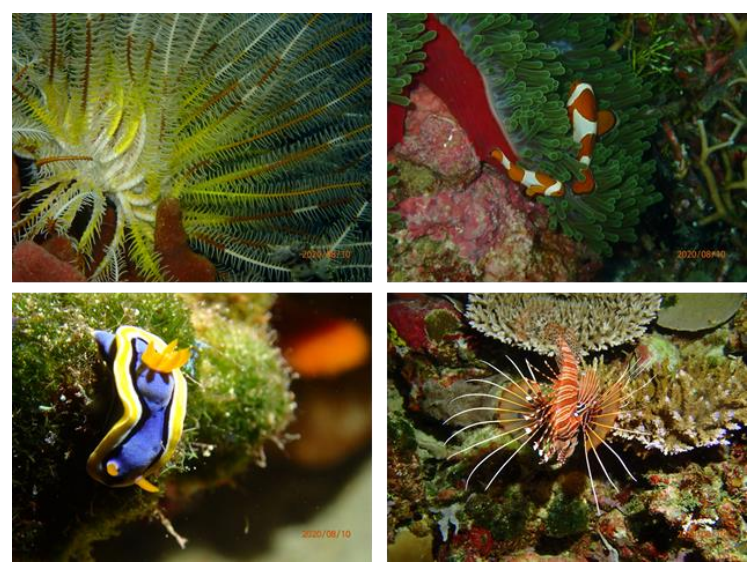

Gambar 1. Keindahan bawah laut Pulau Tomia Sumber: Alfi Hidayat, 2020. (Foto pribadi)

Yayasan Konservasi Alam Nusantara (2019) melaporkan bahwa terdapat 156 jenis burung di Wakatobi dan 11 di antaranya merupakan endemik Indonesia serta 4 di antaranya endemik Wakatobi. Keempat spesies tersebut antara lain Otus kalidupae, Zosterops chloris flavissimus, Dicaeum celebicum kuehni, dan Zeostrops sp. nov. Selanjutnya, Desa Tampara yang dikenal sebagai tempat wisata mangrove di Kaledupa dapat ditemui 25 spesies burung, baik jenis residen/menetap maupun jenis bermigrasi. Hasil penelitian yang dilakukan Sawitri \& Iskandar (2012) melaporkan perbandingan indeks keragaman mangrove di Taman Nasional Wakatobi dan Taman Nasional Kepulauan Seribu. Hasilnya meskipun nilai keragaman jenis mangrove di kedua taman nasional tersebut rendah, tetapi indeks keragaman di 
Wakatobi masih lebih tinggi $\left(\mathrm{H}^{\prime}=1.06\right.$ hingga 1.20$)$ dari Kepulauan Seribu ( $\mathrm{H}^{\prime}=0.76$ hingga 1.02).

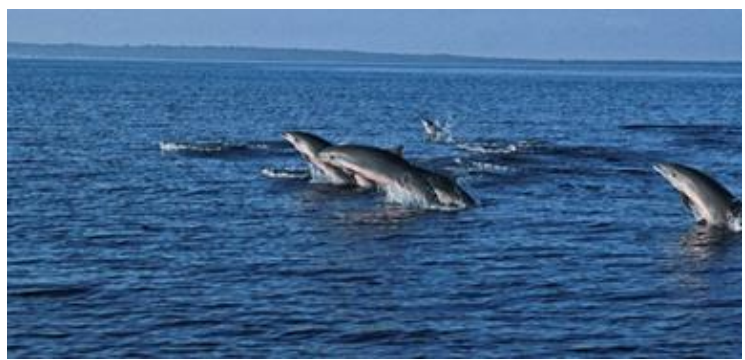

Gambar 2. Atraksi migrasi lumba-lumba di perairan Wangi-Wangi dan Kapota

Sumber: Amal Hermawan, 2017. (Foto pribadi)

Lanskap yang memiliki komposisi baik background, middleground, dan foreground yang selaras, bersih dan alami umumnya dilaporkan sebagai lanskap yang indah (Syahadat et al., 2020; Yulianti et al., 2020). Oleh karena itu keindahan pantai-pantai di Wakatobi tidak dapat diragukan lagi (Darman et al., 2020; Dinas Pariwisata Pemda Wakatobi, 2012). Setiap pulau yang ada di Wakatobi memiliki kualitas yang tinggi. Hal ini dapat dilihat dari indikator kualitas pesisir seperti pasir putih yang luas, kecerahan perairan yang tinggi, penutupan lahan alami, ekosistem utuh, dan cenderung aman dari bahaya (Makalew et al., 2013; Putra et al., 2018; Yusiana et al., 2011). Pulau Wangi-Wangi memiliki pantai yang unik yang bernama Moli'i Sahatu yang bermakna seribu mata air karena di pantai ini terdapat banyak mata air tawar. Terdapat pula pantai yang menawarkan keindahan vegetasi penyusunnya seperti Pantai Cemara di Wangi-Wangi, karena banyak ditemukan pohon cemara dan Pantai Tanjung Sombano di Kaledupa yang memiliki dominasi vegetasi mangrove dan hutan pantai. Bagian timur Pulau Tomia yang meliputi Huntete dan Kulati, terbentang lanskap pasir putih yang cukup luas. Namun, lanskap pantai di timur Pulau Tomia ini belum dikembangkan secara optimal. Selanjutnya, Pantai One Melangka di Binongko juga menjadi salah satu objek wisata unggulan karena memiliki garis pantai yang cukup panjang (Wakatobi Tourism Authority, 2019; Darman et al., 2020; Dinas Pariwisata Pemda Wakatobi, 2012)

Untuk wisata alam lainnya terdapat Puncak Kahiyanga di Tomia yang menyajikan atraksi landscape watching berupa hamparan padang rumput di atas bukit (Dinas Pariwisata Pemda Wakatobi, 2012). Atraksi ini bisa dikatakan unik karena hanya di Tomia yang memiliki struktur ekologi seperti ini meskipun hal semacam ini mungkin bisa ditemukan di daerah luar Wakatobi. Struktur geologi di Binongko sangat berbeda dengan ketiga pulau besar di Wakatobi. Kondisi geologinya didominasi batugamping serta tanah batu karang serta sedimen dan metamorf. Keberadaan tanah sangat sukar ditemukan. Dengan kearifan lokal masyarakat, setiap hari mereka membawa limbah dapur, lalu dimasukkan ke dalam lubang-lubang batu di lahan kebun mereka untuk menanam tanaman. Luasnya lahan batuan dan tanah yang khas ini menciptakan lanskap sebagai satu atraksi unik tersendiri di selatan pulau yakni Taman Batu Waloindi (Wakatobi Tourism Authority, 2019; Darman et al., 2020). Sebelum mencapai Taman Batu Waloindi ini juga dapat disaksikan pemandangan langka yakni hamparan kebun pisang yang tumbuh di atas batu [Gambar 3].
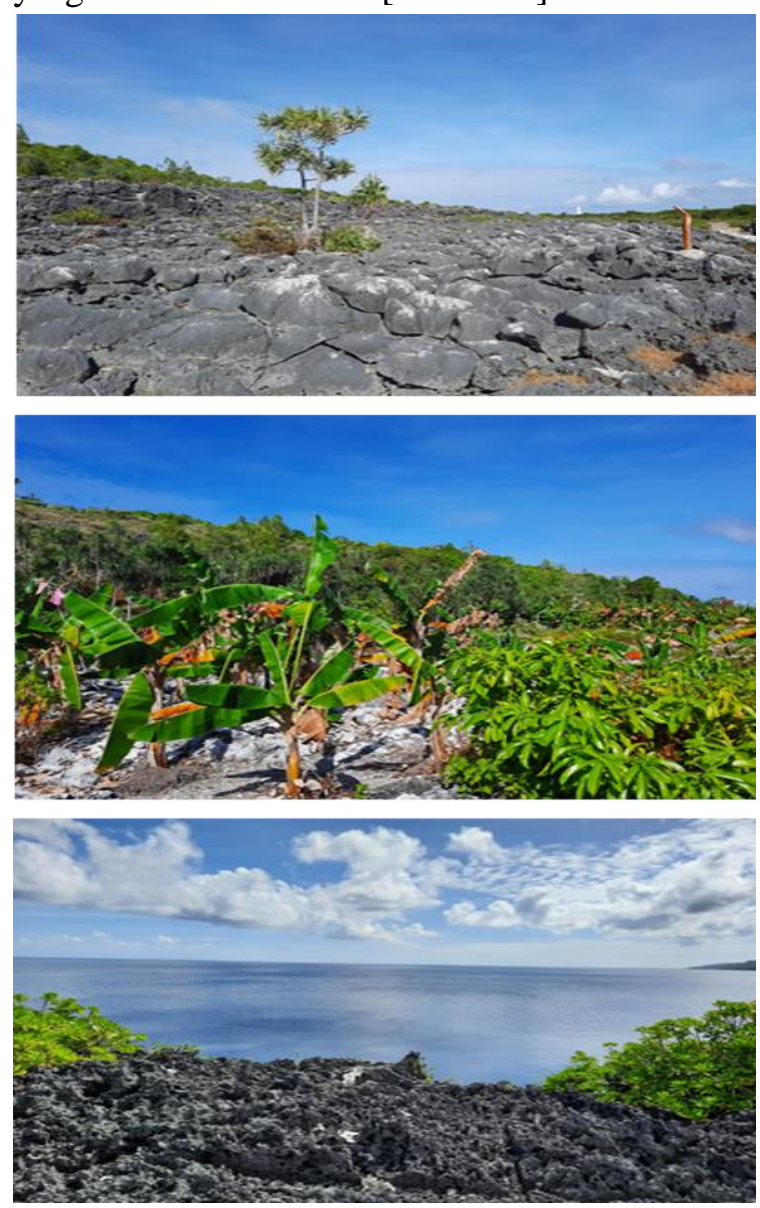

Gambar 3. Lanskap geologi bebatuan di Pulau Binongko Sumber: Penulis, 2020. 
Terdapat pula beberapa gua di Wakatobi dan gua unik berada di dekat Desa Soa, Popalia, dan Haka di Binongko. Gua ini memiliki badan air di dalamnya sehingga untuk menikmati stalaktit dan stalagmit harus dengan cara diving. Oleh karena itu, atraksi diving di daratan Wakatobi hanya dapat ditemukan di Binongko. Pamor gua-gua di Wakatobi mungkin masih lebih rendah dibandingkan dengan tetangganya di Sulawesi Tenggara yakni Kabupaten Buton Tengah yang dikenal sebagai negeri seribu gua (Kamil, 2017). Meskipun demikian, jika dikelola dengan baik tidak menutup kemungkinan atraksi cave diving dapat berkembang seperti di daerah lain di Indonesia (Harmony \& Pitoyo, 2012).

\section{Objek Daya Tarik Wisata Sejarah}

Peninggalan sejarah di Wakatobi umumnya merupakan benteng-benteng yang dulunya merupakan kesatuan sistem dengan seluruh benteng di wilayah eks Kerajaan dan Kesultanan Buton. Benteng Keraton Liya Togo yang memiliki karakter benteng berlapis-lapis dan terdapat perkampungan adat, masjid, balai, dan makam bersejarah di dalamnya (Eulisa et al., 2017). Beberapa benteng lainnya juga dapat ditemukan di pulau ini seperti Benteng Tindoi, Benteng Maleko, Benteng Mandati Tonga, Benteng Wabue-bue, Benteng Koba, dan Benteng Wantiti. Terdapat pula dua benteng yakni Benteng Katiama dan Benteng Togo Molengo di Pulau Kapota, yang berjarak 15 menit dari Pulau Wangi-Wangi (Ali et al., 2019; Ihsyaluddin, 2014). Selain Benteng Liya Togo, nampaknya bentengbenteng lain di Pulau Wangi-Wangi dan sekitarnya belum dikembangkan maupun dikelola. Hal ini terlihat dari kondisi benteng yang tidak terawat bahkan nyaris rusak, serta akses yang kurang memadai.

Pulau Kaledupa juga memiliki beberapa benteng seperti Benteng Ollo, Benteng Palea, Benteng Ladonda, Benteng Tapa'a, Benteng Horuo, Benteng La Manungkira, Benteng Pangilia, dan Benteng La Bohasi (Ihsyaluddin, 2014). Permukiman adat di Pajam yang dikelilingi Benteng Palea merupakan salah satu peninggalan Barata Kahedupa yang masih dapat ditemui. Selain Desa Pajam, peninggalan Barata Kahedupa lainnya yang masih eksis dan terawat baik yakni Benteng Ollo.
Jika merunut berdasarkan sejarah, peradaban di Kaledupa diawali di Pajam, kemudian turun ke Buranga tempat Benteng Ollo berada, kemudian berkembang ke Ambeua. Benteng Ollo memiliki peran bukan hanya sebagai pusat pertahanan dan keamanan tetapi juga fungsi pemerintahan dan permukiman. Permukiman di Benteng Ollo juga memiliki nilai signifikansi karena tradisi dan budaya masih dilaksanakan dan dijunjung tinggi oleh masyarakat setempat. Beberapa peninggalan sejarah seperti masjid, istana, dan makam bersejarah juga ada di lanskap Benteng Ollo (Qifli \& Hadara, 2017; Sope \& Kasmiati, 2017; Wakatobi Tourism Authority, 2019; Dinas Pariwisata Pemda Wakatobi, 2012).

Seperti halnya di Wangi-Wangi dan Kaledupa, daratan Pulau Tomia juga memiliki benteng yaitu Benteng Patua, Benteng Suo-Suo, dan Benteng Rambi Randa (Ihsyaluddin, 2014; Umar, 2018). Dua benteng yakni Rambi Randa dan Benteng Kanamua berada di Pulau Lentea. Kondisi Benteng Patua masih sangat terawat meskipun tidak terdapat permukiman di dalamnya seperti pada Benteng Liya Togo, Benteng Palea, dan Benteng Ollo. Dulunya memang ada permukiman di sekitar Benteng Patua tetapi karena perkembangan zaman, masyarakat bermigrasi ke wilayah pesisir sekitar Waha. Dahulu ada tradisi ketika menaiki benteng dengan menggunakan egrang. Tradisi ini memang sudah tidak dilakukan lagi sekarang tetapi ketika festival maupun penyambutan tamu, dipertontonkan lagi kepada pengunjung.

Selanjutnya, benteng di Pulau Binongko jumlahnya cukup banyak seperti, Benteng Taduno, Benteng Oihu, Benteng Koto-Koto, Benteng Watuua, Benteng Wacu Awa, Benteng Tohalo, Benteng Wali, Benteng Koncu Patua, dan Benteng Palahidu. Tiga buah benteng yakni Benteng Haka, Benteng Fatiwa, dan Benteng Baluara ada dalam informasi Peraturan Daerah Nomor 12 tentang RTRW Kabupaten Wakatobi 2012 hingga 2032, namun tidak diketahui oleh penduduk lokal. Kemungkinan ketiga benteng ini memang belum dieksplorasi atau adanya perbedaan nama antara warga lokal dan RTRW. Benteng Palahidu merupakan benteng yang cukup luas, mudah dijangkau, dan memiliki beberapa makam tua dengan struktur yang berbeda dengan makam- 
makam yang ada di Kepulauan Sultra (Dinas Pariwisata Pemda Wakatobi, 2012). Benteng Tanduno juga mudah dijangkau dan berdekatan dengan objek Taman Batu Waloindi dan mercusuar peninggalan zaman kolonial (Wakatobi Tourism Authority, 2019). Meskipun demikian, sangat disayangkan kondisi benteng-benteng lainnya di Binongko bisa dikatakan banyak yang tidak terawat dan bahkan rusak. Hal ini disebabkan karena belum ada perlindungan hukum sebagai cagar budaya di Wakatobi.

Pulau Binongko juga memiliki banyak gua dan makam bersejarah. Tidak menutup kemungkinan masih banyak gua yang belum dieksplorasi. Inventarisasi gua yang ada di Wakatobi pernah dilakukan oleh Tondi \& Ahmad (2016) namun dalam laporannya tidak terdapat gua di Pulau Binongko. Hal ini sangat bertolak belakang dengan kondisi di lapangan. Salah satu gua dilaporkan oleh perangkat Kecamatan Binongko, ditemukan kerangkakerangka manusia zaman dahulu. Namun, informasi ini belum dilaporkan kepada pemerintah daerah karena keterbatasan pengetahuan dan sejauh ini juga belum dilakukan penelitian mengenai temuan tersebut. Lokasi gua berada di dataran tinggi dekat Benteng Koncu Patua. Temuan arkeologi ini dirasa perlu dieksplorasi lebih lanjut karena memiliki nilai penting ilmu pengetahuan mengingat budaya perkuburan dalam gua merupakan tradisi bagi banyak kebudayaan kuno di Kepulauan Sulawesi (Gunawan \& Merina, 2018; Hakim, 2017; Marzuki, 2016; Maskuri, 2017; Rismayanti \& Nusarastriya, 2020; Suseno et al., 2019).

\section{Objek Daya Tarik Wisata Budaya}

Wisata budaya yang dapat ditemukan di Wakatobi tidak lepas dari keragaman etnis yang ada di sana. Objek-objek yang dapat ditemukan secara umum dibagi menjadi objek tak wujud dan wujud. Objek tak wujud berupa tradisi dan kesenian sedangkan objek wujud umumnya berupa permukiman adat. Keraton Liya Togo merupakan salah satu perkampungan budaya di Wangi-Wangi yang dikelilingi oleh benteng. Keraton Liya Togo masih menjalankan adat dan tradisi selayaknya pada masa Kerajaan dan Kesultanan Buton. Pada permukiman masih banyak ditemukan arsitektur vernakular khas Wangi-Wangi. Lembaga adat juga masih berjalan di tempat ini (Wakatobi Tourism Authority, 2019).

Budaya di Pulau Kaledupa dan sekitarnya memiliki keistimewaan Wakatobi yang tak lepas dari keberadaan Barata Kahedupa. Tidak mengherankan banyak peninggalan yang autentik di daerah ini. Permukiman adat di Desa Pajam yang dikelilingi Benteng Palea bisa dikatakan sebagai pusat kebudayaan di Kaledupa. Sistem adat masih dipegang di wilayah ini. Desa ini juga dikenal sebagai desa tenun boke. Tenun boke merupakan tenun ikat khas Kaledupa yang memiliki tingkat kerumitan tersendiri karena menggunakan teknik khusus dan penggunaan bahan-bahan alami (Atima et al., 2019). Desa Pajam juga dikenal sebagai penghasil bawang merah sejak zaman dahulu, namun saat ini produksinya menurun karena serangan penyakit. Setiap tahunnya Festival Barata Kahedupa dilaksanakan di desa ini. Permukiman adat di Benteng Ollo di Buranga dan di Ambeua juga unik karena didominasi penggunaan arsitektur vernakular berupa rumah panggung.

Selanjutnya di Pulau Binongko setidaknya dapat ditemukan tiga objek perkampungan yang khas karena menjalankan tradisi budaya tak benda. Desa Haka sebagai kampung pembuat kapal tradisional yang masih lestari, ketika daerah lain di kepulauan Sultra telah meninggalkan tradisi ini. Penamaan Kepulauan Tukang Besi sebelum nama Wakatobi eksis sejarahnya pun berasal dari Pulau Binongko. Bukti historis itu masih dapat ditemukan di Desa Soa dan Popalia sebagai kampung pandai besi (Dinas Pariwisata Pemda Wakatobi, 2012). Persenjataan Kerajaan dan Kesultanan Buton dulunya diproduksi di Binongko. Bahkan berdasarkan tutur masyarakat, parang Kapitan Pattimura pahlawan nasional asal Kepulauan Maluku pun berasal dari Binongko. Ketika dikonfirmasi mengenai cerita ini, masyarakat selalu menunjukkan mata uang seribu yang memang mata parangnya menyerupai bentuk parang khas Binongko. Kedua desa yang berada di barat pulau ini juga dikenal sebagai kampung tenun ikat. Teknik dan coraknya serupa dengan yang ditemukan di 
Kaledupa, namun jika dilihat detail terdapat perbedaan di antaranya.

Keberadaan etnis Sama Bajau atau Bajo juga mewarnai budaya di Wakatobi. Setidaknya terdapat empat kampung adat Bajo di Wakatobi yakni Mola, Sampela, Mantigola, dan Lohoa. Pemimpin etnis Bajo seluruh dunia tinggal di Mola sehingga bisa dikatakan pusat budaya Bajo. Karakter permukiman Bajo di Mola, sudah menginvasi daratan meski masih menjalankan budaya maritimnya yang unik (Eryano et al., 2020; Herlina et al., 2020; Marlina et al., 2020, Marlina et al., 2021; Tim Ekskursi Wakatobi, 2013). Berdasarkan penilaian yang berdasarkan Peraturan Daerah Nomor 1 Tahun 2017 tentang Pencegahan dan Peningkatan Kualitas terhadap Perumahan Kumuh dan Permukiman Kumuh di Kabupaten Wakatobi, permukiman Mola masuk ke dalam permukiman kumuh bahkan terbesar di Wakatobi dengan persentase sebesar 24\%. Tiga permukiman Bajo lainnya yakni Bajo Sampela, Bajo Lohoa, dan Bajo Mantigola berada di Kaledupa. Ketiga permukiman Bajo ini berbeda karakternya dengan Bajo Mola di Wangi-Wangi. Hal yang membedakannya yaitu permukiman Bajo di perairan sekitar Kaledupa masih berada di atas laut dan lebih tradisional meskipun masih menerapkan kebudayaan yang sama (Hasrawaty et al., 2017; Nurhaliza \& Suciati, 2019; Suryanegara et al., 2015).

Keragaman tradisi dan seni yang ada di Wakatobi juga orisinal, autentik, dan unik. Pulau Wangi-Wangi dan sekitarnya memiliki beberapa tradisi dan kesenian seperti Tradisi Kabuenga, Tradisi Karia, Tarian Kenta-Kenta, Tarian Honari Mosega, dan lainnya yang memiliki nilai penting bagi masyarakat setempat (Ali et al., 2019; Alifuddin, 2013; Bini et al., 2018; Suni \& Badollahi, 2020). Tradisi dan kesenian tersebut masih sering ditampilkan pada kegiatan festival budaya di Wangi-Wangi. Tari Kenta-Kenta dimainkan oleh anak-anak memiliki keunikan tersendiri. Tarian ini memiliki nilai edukasi di dalamnya karena mengajarkan cara melaut secara tradisional yang ramah lingkungan. Tradisi-tradisi ini dapat disaksikan oleh khalayak pada Festival Wakatobi WAVE.

Salah satu peninggalan tak benda yang dapat dikatakan menjadi ciri khas Kaledupa adalah Tarian Lariangi [Gambar 4]. Lariangi secara harfiah berasal dari dua suku kata yakni lari yang bermakna berhias dan angi yang bermakna berpesan sehingga dapat dimaknai sebagai orang yang berhias dan menyampaikan pesan. Tarian ini menggunakan bahasa Kaledupa kuno yang saat ini sudah tidak dipahami maknanya meskipun masih tetap dilestarikan. Pakaian dan riasan yang digunakan juga sangat berbeda dengan budaya lain di Kepulauan Wakatobi bahkan Kepulauan Buton. Oleh karenanya, pakaian Lariangi biasanya dijadikan grafis promosi wisata di Wakatobi. Tarian Lariangi juga menggunakan seperangkat alat musik gamelan dan memiliki corak Hinduisme pada pembukaannya serta gerakan lambat dengan ekspresi datar seperti Tarian Serimpi di Jawa (Sofian, 2018). Dengan segala keunikan yang dimiliki tarian ini, Pemerintah Daerah Wakatobi sedang berupaya mengusulkan untuk mendaftarkan Lariangi agar menjadi warisan dunia tak benda oleh UNESCO. Seluruh atraksi budaya ini juga ditampilkan pada Festival Barata Kahedupa setiap bulan September.

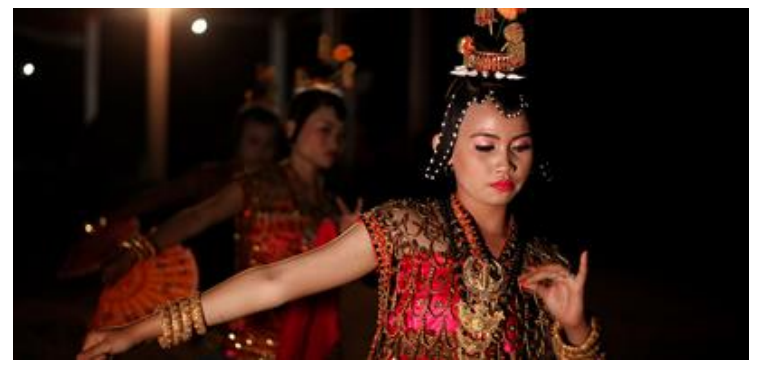

Gambar 4. Tarian Lariangi

Sumber: Amal Hermawan, 2017. (Foto pribadi)

Berbeda dengan pulau-pulau lainnya, wujud fisik kebudayaan di Tomia sudah sukar ditemukan karena perubahan sosial. Meskipun demikian masyarakat di Tomia masih memegang teguh budaya, adat, dan tradisi sebagai pusaka tak benda. Budaya di Pulau Tomia secara corak masih sama dengan Kepulauan Buton secara umum dan Wakatobi secara khusus. Hal yang membedakannya lebih kepada tradisi seni dan linguistik. Salah satu seni yang menarik di Tomia adalah Tarian Sajo Moane atau kadang disebut sebagai Tari Eja-Eja. Tarian ini dimainkan oleh sekelompok anak lakilaki yang menceritakan semangat berperang yang 
konon katanya menceritakan perlawanan dengan Bangsa Portugis. Tarian sakral ini menggunakan kostum yang khas dan hanya dapat ditemukan di Tomia saja. Tarian ini juga dimainkan sambil bernyanyi dan diiringi oleh alat musik tradisional. Tradisi dan kesenian di Pulau Tomia selalu ditampilkan pada Festival Benteng Patua (Mokodompit et al., 2015). Kemudian Festival ini berkembang menjadi Festival Pulau Tomia yang dilaksanakan seusai Idul Fitri.

Atraksi budaya yang juga menjadi ciri khas Binongko yakni Tari Balumpa (Wakatobi Tourism Authority, 2019; Dinas Pariwisata Pemda Wakatobi, 2012). Balumpa sendiri bermakna berjingkrak. Tarian ini dulu menjadi ikon Sulawesi Tenggara dan digunakan untuk menyambut tamu karena bernuansa penuh akan keceriaan. Jauh sebelum dijadikan tarian penyambutan, Tari Balumpa dulunya dimainkan untuk menggambarkan kebahagiaan masyarakat dalam mengarungi ombak ketika mencari nafkah. Irama musik gambus dan gendang serta gerakannya memiliki corak yang mirip dengan Tarian Zapin di tanah Melayu. Berbeda dengan tarian lainnya di Wakatobi yang dimainkan sambil bernyanyi, penari Tari Balumpa hanya melakukan gerakan empat ragam tarian (pothabea, poliughi, poli-poli, dan kaukuruno siku) tanpa bernyanyi. Nyanyian dilakukan oleh kelompok pemain musik. Pakaian adat yang digunakan masih serupa dengan pakaian di Buton. Tari Balumpa juga dapat ditemukan di Buton Utara namun gerakannya berbeda, terutama pada gerakan tangan. Temponya juga sedikit lebih lambat dari Balumpa Binongko. Tentunya nyanyiannya juga berbeda karena faktor perbedaan bahasa.

Terdapat permainan tradisional yang unik juga hanya dapat ditemukan di Binongko. Permainan tradisional tersebut merupakan kapal mini yang dimainkan di laut seperti memainkan layangan. Sebutan permainan ini yakni kabangka-bangka. Tradisi permainan ini selalu dilombakan pada Festival Tukang Besi pada bulan Maret atau April. Kata bangka sendiri memiliki tiga makna. Pertama dapat bermakna kapal. Kedua dapat bermakna spesifik jenis kapal tradisional Buton. Ketiga dapat bermakna teman. Kata teman ini memiliki makna filosofis yang dalam bagi masyarakat eks Kerajaan dan Kesultanan Buton sebagai negara maritim pada masa lalu. Semboyan sabangka sarope menggambarkan persatuan yang diibaratkan negara selayaknya kapal. Selanjutnya, persaudaraan diibaratkan sebagai hal yang vital untuk menjaga labuan dan buritan kapal dalam keseimbangan kapal untuk mencapai tujuan. Tanpa adanya kerja sama, hanya akan memperburuk keadaan. Dengan demikian nilainilai kebersamaan dan toleransi telah lama diterapkan dan dihayati oleh masyarakat. Oleh karena itu kemaritiman merupakan unsur budaya penting dan tidak dapat dipisahkan di Kepulauan Sultra pada umumnya dan Wakatobi khususnya (Hamid, 2011; Tim Infografik Kompas, 2014; Wijaya, 2016).

\section{Rekomendasi untuk Perencanaan Pariwisata Wakatobi}

Perencanaan merupakan langkah awal sebagai persiapan sebelum memulai suatu kegiatan. (Rejeki \& Hantoro, 2020). Menurut Pitana \& Diarta (2009), perencanaan pariwisata terdiri dari sembilan tahapan. Tahapan tersebut dimulai dari penentuan usaha yang ingin dijalankan, penentuan tujuan, pengumpulan informasi dan pengetahuan, menganalisis informasi, penyusunan strategi, pendistribusian sumber daya, pengimplementasian rencana, serta kontrol dan monitor. Fenomena yang terjadi saat ini di Wakatobi nampaknya masih lemah pada tahap pengumpulan informasi dan pengetahuan, yang disebabkan titik fokus masih terbatas pada objek daya tarik wisata dengan sifat sejenis.

Berdasarkan hasil identifikasi objek daya tarik wisata di Wakatobi, sesungguhnya Wakatobi tidak hanya alam bawah laut saja. Banyak objek baik alam, sejarah, dan budaya yang memiliki nilai orisinalitas, autentisitas, unik, dan indah. Banyaknya objek juga menunjukkan terpenuhinya aspek keragaman sebagai tempat wisata yang lengkap. Permasalahannya pokok dalam perencanaan wisata di Wakatobi adalah ketidakpahaman mendalam mengenai apa yang ingin ditonjolkan dan apa yang menjadi ciri khas sebagai pembeda. Sebagai contoh jika mengacu dalam official website pariwisata Wakatobi dan situs 
resmi Pemerintah Daerah Wakatobi, objek-objek yang ditampilkan tidak memberikan informasi yang lengkap, masih terkesan bingung untuk menyorot objek utama, dan tidak menampilkan gambar yang fenomenal.

Ikon wisata memiliki peran yang penting untuk menjaga keberlanjutan pariwisata (Becken, 2005). Wakatobi hanya memiliki 3\% wilayah daratan dari total luas wilayahnya, mengakibatkan adanya keterbatasan dalam mencari lanskap yang ikonik untuk menjadi wajah utamanya. Terumbu karang memang menjadi daya tarik utama tetapi hanya orang yang mengerti yang mampu mendeskripsikan nilai keindahan terumbu karang tersebut. Berbeda dengan Raja Ampat dan Komodo yang meskipun memiliki atraksi wisata alam yang mirip dengan karakter Wakatobi, tetapi mereka memiliki Puncak Pianemo dan Puncak Padar sebagai lanskap ikonik yang mudah dipahami langsung.

Fakta bahwa Wakatobi bukanlah satu tetapi empat merupakan faktor penting yang harus dilihat. Berdasarkan penjelasan dari bab sebelumnya, dapat disimpulkan bahwa setiap pulau memiliki daya tarik tersendiri. Jika dilihat dari official website pariwisata Wakatobi sesungguhnya sudah ada upaya untuk memperkenalkan potensi keempat pulau. Bahkan dari events calendar, setiap pulau sudah memiliki festival besar yang menjadikan Wakatobi menjadi satu-satunya daerah di Sulawesi Tenggara yang memiliki events calendar. Namun jika dilihat lebih dalam, ada dua kelemahan yang dimiliki. Pertama, penjelasan bahwa Wakatobi itu empat masih kurang tajam. Hal ini mengakibatkan, wisatawan yang akan datang mungkin hanya akan terkonsentrasi pada satu pulau saja dan pulau yang memiliki akses yang mudah dijangkau saja yang nantinya akan menjadi pemenang. Kedua, memaknai keragaman antar pulau masih terbatas. Wangi-Wangi dideskripsikan "All roads lead to Rome and in Wakatobi all travels". Kaledupa dideskripsikan "Before the arrival of the Butonese in Wakatobi". Tomia dideskripsikan "As the island with the largest number of dive sites". Kemudian Binongko dideskripsikan "Binongko might be the last abbreviation in the name". Melalui empat kalimat itu, nampaknya hanya Kaledupa dan Tomia saja yang mudah untuk dipahami terhadap objek yang dapat dinikmati.

Sebagai dasar untuk perencanaan wisata di Wakatobi, maka perlu ada pengelompokkan yang menguatkan objek pada masing-masing pulau. Bila dikelompokkan, Wangi-Wangi dapat menonjolkan lumba-lumba sebagai ikonnya. Hal ini dikarenakan hanya di perairan antara Wangi-Wangi dan Kapota saja atraksi ini dapat dinikmati, mudah dijangkau, dan waktunya sudah dapat diketahui. Kaledupa lebih cocok untuk menonjolkan wisata sejarah dan budaya berbasis pendidikan. Hal ini disebabkan banyaknya peninggalan sejarah dan budaya di sana mulai dari sebelum hingga adanya pengaruh dari budaya Buton. Terlebih lagi pada Tarian Lariangi yang biasa menjadi ikon, memiliki nilai orisinalitas, autentisitas, keunikan, dan keindahan yang hanya dapat ditemui di Kaledupa. Pulau ini juga tempat tiga permukiman Bajo yang memiliki budaya yang unik dan cenderung belum berubah. Tomia dianggap tepat menonjolkan wisata alam bawah lautnya karena memiliki jumlah dive sites yang banyak dan telah lebih dulu mendunia. Titik selam Marimabok merupakan titik yang dapat menjadi ikon. Kemudian Binongko lebih tepat menunjukkan geologinya sebagai pulau batu yang unik. Keunikan ini menciptakan lanskap Taman Batu Waloindi dan budaya pandai besi yang tak lepas dengan budaya batu. Selama ini yang ditonjolkan di Binongko lebih condong ke atraksi budaya pandai besi saja. Namun, nampaknya tidak semua orang memahami nilai pentingnya karena hanya sebatas orisinal dan autentik lokal. Oleh karena itu rasanya perlu pula ditonjolkan keindahan lanskap bebatuannya yang unik sebagai ikon. Keempat ikon ini tidak hanya akan menonjolkan wisata di Wakatobi tetapi juga adanya hubungan saling melengkapi.

Pembangunan infrastruktur wisata yang merata untuk menghubungkan keempat pulau utama sangat perlu untuk direalisasikan. Hal ini berguna untuk mendukung peningkatan pamor Wakatobi yang memiliki keragaman objek daya tarik wisata. Objek daya tarik wisata perlu diikat dengan infrastruktur sehingga dapat memperkuat citra destinasi. Citra yang baik akan menimbulkan kesan yang baik pula dan membangkitkan minat kunjungan ulang dan mendorong berkembangnya usaha pariwisata (Syarifuddin, 2018; Suwantoro, 
2004). Selama ini terlihat adanya kecenderungan pembangunan infrastruktur lebih banyak diutamakan di Pulau Wangi-Wangi. Tidak mengherankan karena Wangi-Wangi merupakan ibukota kabupaten. Meskipun demikian, dalam dokumen-dokumen perencanaan di Wakatobi umumnya telah ada rencana pembangunan infrastruktur di setiap pulau meskipun belum semuanya terwujud hingga hari ini.

Akses untuk menuju Wakatobi dapat melalui dua jalur yakni jalur udara dan laut. Pada jalur laut terdapat Pelabuhan Pangulubelo di Wangi-Wangi. Pelabuhan ini merupakan pelabuhan terbesar yang juga berfungsi sebagai pelabuhan pengumpul dengan jaringan trayek nasional maupun regional. Selain itu, masing-masing pulau besar lainnya juga dapat dijumpai pelabuhan pengumpan yang melayani trayek regional. Pelabuhan-pelabuhan tersebut antara lain Pelabuhan Buranga di Pulau Kaledupa, Pelabuhan Waha di Pulau Tomia, dan Pelabuhan Rukuwa di Pulau Binongko. Khusus untuk Pulau Binongko, keberadaan Pelabuhan Rukuwa nampaknya belum cukup karena kondisi geografisnya yang memiliki kendala terhadap gelombang laut. Pelabuhan Rukuwa hanya aman dilabuhi saat musim angin barat.

Gerbang jalur udara dapat melalui Bandar Udara Matahora di Wangi-Wangi dan Maranggo Air Strip di Tomia. Maranggo Air Strip merupakan fasilitas yang dibuat oleh WDR yang melayani penerbangan privat dari Bali. Adanya fasilitas penerbangan terlihat cukup berpengaruh terhadap kunjungan wisatawan. Terlihat pada Tabel 2 jumlah kunjungan Pulau Wangi-Wangi dan Tomia merupakan pulau dengan kunjungan paling tinggi pada tahun 2019 sebelum masa pandemi. Kunjungan Wisatawan Nusantara (Wisnus) di Wangi-Wangi lebih tinggi dibandingkan Wisnus di Tomia. Hal ini berbalik dengan kunjungan Wisatawan Mancanegara (Wisman) yang lebih tinggi di Tomia dibandingkan Wangi-Wangi. Dengan demikian dapat disimpulkan bahwa tingkat kunjungan wisata yang rendah pada pulau lain di Wakatobi bukan berarti tidak memiliki daya tarik tetapi lebih dikarenakan aksesnya yang belum terbuka.

Sejauh ini beberapa pembangunan infrastruktur dasar sudah dilaksanakan namun terdapat beberapa catatan dalam pelaksanaannya. Kapasitas listrik satu Kabupaten Wakatobi sebesar 8,616 kVA. Hanya Pulau Wangi-Wangi dan Tomia yang dapat merasakan listrik 24 jam meskipun masih sering terjadi pemadaman. Tentunya hal ini menjadi salah satu permasalahan serius karena akses listrik memiliki peran yang krusial dengan tren wisata dewasa ini. Selanjutnya, sanitasi dan pengolahan sampah di empat pulau utama nampaknya belum tercapai. Jalan lingkar empat pulau utama ke objek wisata belum menyeluruh. Panjang jalan terpanjang masih didominasi di pulau tempat ibukota berada yaitu Pulau Wangi-Wangi dengan panjang jalan $198.985 \mathrm{~km}$, disusul Pulau Tomia 127.221 km, lalu Pulau Kaledupa 89.845 km, dan Pulau Binongko sebagai pulau paling luar sebesar $74.221 \mathrm{~km}$. Khusus Pulau Binongko, keadaan infrastruktur jalannya hanya mengitari pulau dari sisi terluar dan kondisinya banyak yang rusak. Berdasarkan informasi dari Badan Perencanaan Pembangunan Daerah (BAPPEDA) Kabupaten Wakatobi hingga akhir tahun 2020, kondisi jalan yang baik sebesar $28.58 \%$, sedang $17.47 \%$, rusak ringan $31.77 \%$, dan rusak berat sebesar $22.18 \%$. Artinya akses daratan di Wakatobi juga masih terbilang buruk.

Tabel 2. Jumlah kunjungan wisatawan pada masing-masing pulau di Wakatobi tahun 2019

\begin{tabular}{|c|c|c|c|}
\hline \multirow[t]{2}{*}{ Pulau } & \multicolumn{2}{|c|}{ Total Kunjungan } & \multirow[t]{2}{*}{ Jumlah } \\
\hline & Wisnus & Wisman & \\
\hline $\begin{array}{l}\text { Wangi- } \\
\text { wangi }\end{array}$ & 9,283 & 1,777 & 11,060 \\
\hline Kaledupa & 3,225 & 875 & 4,100 \\
\hline Tomia & 7,927 & 2,598 & 10,525 \\
\hline Binongko & 2,658 & 514 & 31,72 \\
\hline Total & 23,093 & 5,764 & 28,857 \\
\hline
\end{tabular}

Sebagian besar sarana akomodasi yang ada di Wakatobi umumnya yaitu penginapan sederhana dan homestay yang dikelola oleh masyarakat. Keberadaan hotel serta resort jumlahnya masih sangat terbatas. Selanjutnya, konsentrasi fasilitas akomodasi di Kabupaten Wakatobi masih berada di Pulau Wangi-Wangi. Adapun rinciannya yakni Pulau Wangi-Wangi sebanyak 36 akomodasi, 10 
akomodasi di Pulau Kaledupa, 14 akomodasi di Pulau Tomia, dan paling sedikit berada di Pulau Binongko hanya 3 akomodasi. Hal ini juga menjadi kendala Wakatobi sebagai sebuah destinasi. Padahal idealnya untuk karakter Wakatobi yang berpulaupulau seperti Maladewa, seharusnya terdapat fasilitas akomodasi penginapan minimal satu pulau, satu resort atau penginapan yang memadai (dell'Agnese, 2018).

Usaha restoran dan rumah makan di Kabupaten Wakatobi juga masih terbatas. Data yang dihimpun oleh Dinas Pariwisata pada tahun 2020, diketahui bahwa rumah makan di Wakatobi sebagian besar terdapat di Pulau Wangi-Wangi. Adapun rinciannya di Pulau Wangi-Wangi sebanyak 69 rumah makan, di Pulau Kaledupa sebanyak 4 rumah makan, di Pulau Tomia sebanyak 7 rumah makan, dan 8 rumah makan berada di Binongko. Salah satu hal yang menarik adalah sedikitnya jumlah restoran dan rumah makan di Tomia. Padahal pulau ini merupakan salah satu pulau yang memiliki tingkat kunjungan wisatawan yang tinggi. Informasi yang diperoleh dari pemilik Marind Dive Eco Resort, akibat kelangkaan ini muncul persepsi yang tidak menyenangkan khususnya bagi wisatawan asing terhadap kuliner di Pulau Tomia. Meskipun demikian, sesungguhnya sudah ada pendataan dan pelatihan terhadap pengembangan kuliner di Wakatobi namun hilirisasinya belum tercapai (Dinas Pariwisata Kabupaten Wakatobi, 2019).

Biro dan agen perjalanan wisata juga hanya dapat ditemui di Pulau Wangi-Wangi dan Tomia. Sebanyak 11 biro/agen perjalanan wisata ada di Pulau Wangi-Wangi, sedangkan di Pulau Tomia hanya ada satu. Sebagian besar paket yang ditawarkan adalah paket menyelam dan aktivitas terkait olahraga air. Beberapa biro dan agen juga menyediakan jasa penyewaan alat transportasi darat baik mobil maupun motor. Tidak hanya transportasi darat, tetapi juga transportasi laut berupa kapal kecil, serta penjualan tiket perjalanan.

Pengrajin, UKM, dan kelompok kolaborator untuk pengembangan suvenir di Wakatobi juga kurang berjalan baik. Meskipun para pelaku usaha tetap memproduksi tetapi pemasarannya masih di tempat workshop masing-masing. Hal ini menjadi salah satu kendala yang dikeluhkan wisatawan karena adanya keterbatasan waktu, transportasi, dan juga informasi. Pemerintah sudah melakukan pembinaan terhadap para pelaku usaha tetapi memang belum ada satu tempat yang lengkap untuk menjual aneka suvenir (Dinas Pariwisata Kabupaten Wakatobi; Dinas Penanaman Modal dan Pelayanan Terpadu Satu Pintu Kabupaten Wakatobi, 2020).

$$
\text { Kajian mengenai hubungan }
$$

komplementer dan kompetisi antara destinasi pariwisata 10 Destinasi Pariwisata Prioritas pernah dilaporkan. Kajian ini dianggap penting untuk melihat posisi Wakatobi untuk kemudian dijadikan salah satu pertimbangan dalam perencanaan pariwisatanya. Kajian ini menyimpulkan secara umum pola pintu masuk wisatawan pada 10 Destinasi Pariwisata Prioritas saat ini menghambat pergerakan wisatawan. Hal ini disebabkan ketidakcocokan antara konektivitas kawasan pariwisata prioritas dengan arahan konektivitas saat ini. Wakatobi memiliki hubungan kompetisi dengan Tanjung Kelayang namun kecilnya koefisien hampir tidak berpengaruh. Setiap adanya pertumbuhan pariwisata $1 \%$ di Tanjung Kelayang, akan menurunkan pertumbuhan pariwisata Wakatobi sebesar $0.006 \%$. Selanjutnya, hubungan komplementer ditunjukkan antara Wakatobi dengan Borobudur dan Morotai. Hubungan komplementer Wakatobi dan Morotai didasari oleh kedekatan jarak, tipe atraksi, dan menarik kunjungan wisata minat khusus yang sama yakni diving. Hubungan komplementer dengan Borobudur lebih disebabkan oleh faktor event (Anggraini \& Riyanto, 2017). Berdasarkan fakta dan fenomena yang telah diuraikan sebelumnya, pembangunan infrastruktur pariwisata di Wakatobi yang sudah dirumuskan dalam dokumen-dokumen perencanaan mutlak untuk dilaksanakan. Dengan demikian objek daya tarik wisata yang beragam dan tersebar, dapat diakses oleh calon wisatawan serta dapat meningkatkan pamor Wakatobi.

\section{KESIMPULAN}

Wakatobi tidak hanya memiliki daya tarik wisata akuatik saja. Objek daya tarik wisata alam, sejarah, dan budaya di wilayah terestrial 
juga memiliki nilai orisinalitas, autentisitas, keunikan, keindahan, dan keragaman. Wakatobi tidak dapat diartikan pada satu tempat melainkan empat tempat karena memiliki karakter yang tidak sama dan tidak bisa disamakan. Ikon yang bisa ditonjolkan untuk menjadi kekuatan pada masing-masing empat pulau utama antara lain: 1) atraksi migrasi lumba-lumba untuk Pulau Wangi-Wangi karena orisinal, mudah dijangkau, dan mudah ditemukan sesuai waktu migrasinya; 2) wisata sejarah dan budaya khususnya tradisi Tari Lariangi untuk Pulau Kaledupa karena orisinal, autentik, dan unik, serta memiliki nilai sakral di dalamnya yang disepakati sejak ratusan tahun lalu; 3) keindahan bawah laut untuk Pulau Tomia karena orisinal dan autentik, serta memiliki 40 dive sites yang menawarkan pengalaman yang berbeda-beda; dan 4) lanskap geologi taman batu untuk Binongko karena orisinal, autentik, unik, serta mewarnai corak budaya setempat, dan hanya dapat ditemui di sana. Objek daya tarik wisata yang ada di Wakatobi perlu diikat dengan perencanaan infrastruktur yang menyeluruh pada keempat pulau utama. Umumnya penyebab kurang dikenalnya objek daya tarik wisata di Wakatobi khususnya wilayah terestrial diakibatkan buruknya infrastruktur pariwisata. Oleh karena itu segala rencana infrastruktur yang sesungguhnya sudah tertuang dalam dokumendokumen perencanaan di Wakatobi, sebaiknya diupayakan untuk direalisasikan.

\section{UCAPAN TERIMA KASIH}

Penyusunan artikel ini difasilitasi oleh Dr. Ir. Djoko Wijono, M.Arch dan Prof. Dr. Janianton Damanik M.Si dari Program Doktor Kajian Pariwisata UGM. Selama penyusunan artikel penulis juga mendapatkan banyak bantuan dari Pemerintah Kabupaten Wakatobi khususnya Dinas Pariwisata, BAPPEDA, Dinas Pekerjaan Umum dan Penataan Ruang, serta Dinas Penanaman Modal dan Pelayanan Terpadu Satu Pintu. Selanjutnya Balai Taman Nasional Wakatobi, PHRI Wakatobi, ASITA Wakatobi, Marind Dive Eco Resort, dan seluruh tokoh masyarakat yang tidak dapat disebutkan satu per satu. Kemudian kepada pihak reviewers yang memberikan kritik, saran, serta masukan yang membangun demi kebaikan artikel ini. Oleh karena itu penulis mengucapkan terima kasih atas segala bantuan dan kesempatan yang telah diberikan.

\section{DAFTAR PUSTAKA}

Adji, K. B. (2013). Majapahit (Menguak Majapahit Berdasarkan Fakta Sejarah). Araska, 1-167.

Al Dilwan, M., Astina, I. K., \& Bachri, S. (2019). Pariwisata Wakatobi dalam Perspektif Produksi Ruang. Jurnal Pendidikan: Teori, Penelitian, dan Pengembangan, 4(11), 14961503.

Ali, L., Suyuti, N., \& Udu, S. (2019). Pengembangan Destinasi Wisata Pusaka Saujana di Kecamatan Wangi-Wangi Kabupaten Wakatobi. Jurnal Penelitian Budaya, 4(2), 59-74.

Alifuddin, M. (2013). Dakwah Berbasis Budaya Lokal Telaah atas Nilai-Nilai Dakwah dalam Folksong Orang Wakatobi. Al-Munzir, 6(1), 72-89.

Anggraini, D., \& Riyanto, R. (2017). Analisis Hubungan Komplementer dan Kompetisi antar Destinasi Pariwisata (Studi Kasus: 10 Destinasi Pariwisata Prioritas di Indonesia). Jurnal Kebijakan Ekonomi, 12(2), 224-252.

Arianto, P. (2011). 101 Pesona Sulawesi Tenggara Surga Wisata Alam, Selam, \& Kuliner. Gramedia Pustaka Utama, 169-173.

Atima, Kasim, S. S., \& Anggraini, D. (2019). Pemberdayaan Perempuan Pengrajin Kain Tenun di Desa Pajam Kecamatan Kaledupa Selatan Kabupaten Wakatobi. Jurnal Neo Societal, 4(2), 729-737.

Bala, M., \& Verma, D. (2018). A Critical Review of Digital Marketing . International Journal of Management, 8(10), 321-339.

Baumgarten, A. G. (1983). Aesthetica. Felix Meiner, 1-134.

Becken, S. (2005). The Role of Tourist Icons for Sustainable Tourism. Journal of Vacation Marketing, 11(1), 21-30.

Bini, Anwar, H., \& Batia, L. (2018). Sejarah BantiBanti Pada Masyarakat di Kelurahan Mandati 1 Kecamatan Wangi-Wangi Selatan Kabupaten Wakatobi. Jurnal Penelitian Pendidikan Sejarah UHO, 3(1), 1-17. 
Damanik, J., \& Weber, H. F. (2006). Perencanaan Ekowisata dari Teori ke Aplikasi. CV Andi Offset, 1-142.

Darman, Azis, A., Putra, J. P., Mbau, L. O., Safarni, Mulyono, H., \& Hendrawan. (2020). Buku Informasi Potensi Wisata Alam Taman Nasional Wakatobi. Balai Taman Nasional Wakatobi, 1-108.

dell'Agnese, E. (2018). One Island, One Resort”. Il Turismo Enclave alle Maldive come Eterotopia Pianificata. Bollettino Della Società Geografica Italiana, 14(1), 27-39. (in Italian)

Dinas Pariwisata Kabupaten Wakatobi (2019). Kreasi Wakatobi. Dinas Pariwisata Kabupaten Wakatobi, 1-111.

Dinas Pariwisata Pemda Wakatobi. (2012). Datang dan Nikmati Sensasi Surga Wakatobi. Laut Biru, 1-98

Dinas Penanaman Modal dan Pelayanan Terpadu Satu Pintu Kabupaten Wakatobi (2020). Potensi dan Peluang Investasi Kabupaten Wakatobi. PIIDI \& Qayris Cipta Kreasindo, 24-27.

Diyati, E., \& Rani, F. (2018). Upaya Masyarakat Wakatobi dalam Menjadikan Taman Nasional Wakatobi sebagai Cagar Biosfer Dunia Tahun 2012. JOM FISIP, 5(1), 1-4.

Eryano, L. M., Sudaryono, \& Iskandar, D. A. (2020). Strategi bermukim Suku Bajo di Desa Mola, Kabupaten Wakatobi. Region: Jurnal Pembangunan Wilayah dan Perencanaan Partisipatif, 15(2), 277-288.

Eulisa, E., Ola, L. O., Yunus, L., \& Fitriani. (2017). Penataan Permukiman Di Benteng Liya sebagai Kawasan Konservasi dan Cagar Budaya. JAGAT (Jurnal Geografi Aplikasi Dan Teknologi), 1(1), 63-70.

Fisu, A. A., Ahmad, A., Hidayat, A., \& Marzaman, L. U. (2020). Potential of Mangrove Ecosystem as a Tourism Object Development in Kaledupa Island. Edutourism Journal of Tourism Research, 2(1), 11-17.

Gunawan, R., \& Merina, M. (2018). Tradisi Ma'nene sebagai Warisan Budaya Etnis Toraja. Candrasangkala: Jurnal Pendidikan dan Sejarah, 4(2), 107-115.

Hakim, B. (2017). Interpretasi Awal Temuan Gigi Manusia di Situs Bala Metti, Bone dan Situs Leang Jarie. Jurnal Walennae, 15(1), 19-30.

Hamid, A. R. (2011). Orang Buton: Suku Bangsa Bahari. Penerbit Ombak, 1-341.
Hamid, A. R. (2015). Merangkai Indonesia Lewat Laut: Kisah Pelaut Binongko. Masyarakat Indonesia, 41(2), 177-190.

Harmony, G., \& Pitoyo, A. J. (2012). Kajian Potensi Gua Sebagai Arahan Wisata Minat Khusus Penelusuran Gua di Pulau Nusakambangan. Jurnal Bumi Indonesia, 1(3), 20-28.

Harris, C. W., \& Dines, N. T. (2006). Time-Saver Standards for Landscape Architecture: Design and Construction Data. The McGraw-Hill Companies, 450-530.

Harsana, M., Baiquni, M., Harmayani, E., \& Widyaningsih, Y. A. (2018). Potensi Makanan Tradisional Kue Kolombeng sebagai Daya Tarik Wisata di Daerah Istimewa Yogyakarta. Home Economics Journal, 2(2), 40-47.

Hasrawaty, E., Anas, P., \& Wisudo, S. H. (2017). Peran Kearifan Lokal Suku Bajo dalam Mendukung Pengelolaan Kawasan Konservasi di Kabupaten Wakatobi. Jurnal Penyuluhan Perikanan dan Kelautan, 11(1), 25-34.

Herlina, Juhaepa, \& Supiyah, R. (2020). Eksistensi Masyarakat Suku Bajo dalam Mempertahankan Tradisi Duata (Pengobatan) pada Masyarakat di Desa Mola Selatan Kecamatan Wangi-Wangi Selatan Kabupaten Wakatobi. Gemeinschaft, 2(1), 1-7.

Ihsyaluddin. (2014). Pengembangan Model Ecotourism dalam Rangka Pertumbuhan Hijau di Kabupaten Wakatobi (2013). Jurnal Green Growth dan Manajemen Lingkungan, 3(1), 14-26.

Kamil, S. U. R. (2017). City Branding sebagai Strategi Komunikasi Pariwisata Kabupaten Buton Tengah. Metacommunication: Journal of Communication Studies, 2(1), 1-13.

Killian, G., \& McManus, K. (2015). A Marketing Communications Approach for the Digital Era: Managerial Guidelines for Social Media Integration. Business Horizons, 58(5), 539549.

Lukman, M. Y., Zaki, M., \& Ikhsan, A. M. (2019). Pengembangan Potensi Kawasan Agrowisata Pulau Kaledupa di Kabupaten Wakatobi. Business Horizons, 4(1), 21-29.

Makalew, A. D., Damayanti, V. D., \& Nugraha, J. A. (2013). Perencanaan Lanskap Wisata Pantai Tanjung Baru berbasis Eco-landform. Jurnal Lanskap Indonesia, 5(1), 27-40. 
Marlina, Sumarmi, \& Astina, I. K. (2020) Sustainable Marine Ecotourism Management: A Case of Marine Resource Conservation based on Local Wisdom of Bajo Mola Community in Wakatobi National Park. GeoJournal of Tourism and Geosites, 34(4), 1317-1323.

Marlina, Sumarmi, Astina, I. K., \& Susilo, S. (2021). Social-Economic Adaptation Strategies of Bajo Mola Fishers in Wakatobi National Park. GeoJournal of Tourism and Geosites, 34(1), 14-19.

Marzuki, I. W. (2016). Sebaran Sumber Daya Arkeologi di Kabupaten Morowali: Gambaran Toleransi Masyarakat Masa Lalu. Forum Arkeologi, 29(2), 81-92.

Maskuri, M. (2017). Sebaran Gua Penguburan di Kabupaten Konawe Kepulauan Provinsi Sulawesi Tenggara. Sangia: Journal of Archaeology Research, 1(2), 46-61.

Mokodompit, E. A., Rianse, U., Baka, L. R., \& Ansir. (2015). Social Capital Contribution in Development of Marine Ecotourism in Tomia Island Wakatobi National Park. International Journal of Science and Research, 4(6), 15681575.

Munawaroh, E., Purwanto, Y., Suryanto, J., Ajiningrum, P. S., \& Priatna, D. (2018). Persepsi Lokal terhadap Perubahan Variabel Iklim dalam Mengelola SDAH dan Lingkungannya di Wakatobi, Sulawesi Tenggara. Jurnal Pendidikan Lingkungan Hidup, 6(2), 22-26.

Nurhaliza, W. O. S., \& Suciati, T. N. (2019). Tret Sosial Budaya Masyarakat Suku Bajo Sampela di Kabupaten Wakatobi. Jurnal Komunikasi Universitas Garut: Hasil Pemikiran dan Penelitian, 5(2), 341-356.

Pemerintah Republik Indonesia. (1996). SK Surat Keputusan Menteri Kehutanan RI Nomor 393/Kpts-II/1996 Tentang Taman Nasional Laut Wakatobi. Jakarta: Kementerian Kehutanan.

Pemerintah Republik Indonesia. (2003). UndangUndang Nomor 29 Tahun 2003 Tentang Pembentukan Kabupaten Bombana, Kabupaten Wakatobi, dan Kabupaten Kolaka Utara di Provinsi Sulawesi Tenggara. Jakarta: Sekretariat Negara.

Pitana, I G. \& Diarta, I. K. S. 2009. Pengantar Ilmu Pariwisata. Andi, 109.
Portal Informasi Indonesia. (2020). Pengakuan UNESCO untuk Tiga Cagar Biosfer Indonesia. Portal Informasi Indonesia. https://indonesia.go.id/ragam/keanekaragama n-hayati/ekonomi/pengakuan-unesco-untuktiga-cagar-biosfer-indonesia. [May $18^{\text {th }}$ 2021].

Putra, R. T., Ramadanti, P., Thoifur, D. M., Hestiningsih, H., Ramadhan, R. R., Syahadat, R. M., \& Putra, P. T. (2018). Ecomparism, sebuah Konsep Perencanaan Wisata Pantai Teloek Dalam-Bintan, Provinsi Kepulauan Riau. Jurnal Arsitektur Lansekap, 4(2), 233242.

Qifli, A. Z., \& Hadara, A. (2017). Situs Benteng Ollo Peninggalan Sejarah Barata Kaedupa di Pulau Kaledupa Kabupaten Wakatobi. Jurnal Penelitian Pendidikan Sejarah UHO, 2(2), 39-51.

Ramaddin, Tadjuddah, M., \& Oetama, D. (2019). Karakteristik Biologis Ikan Kerapu di Perairan Karang, Tomia Kabupaten Wakatobi Provinsi Sulawesi Tenggara. Jurnal Manajemen Sumberdaya Perairan, 4(3), 266-273.

Rejeki, S. \& Hantoro, G. D. 2020. Perencanaan dan Pengelolaan Perjalanan Wisata. Rekayasa Sains, 54.

Rismayanti, R., \& Nusarastriya, Y. H. (2020). Upacara Adat Pemakaman Mengenang Leluhur (Ma'Nene) di Toraja, Lembang Bululangkan Kecamatan Rinding Allo Toraja Utara. Jurnal Adat dan Budaya Indonesia, 2(2), 118-132.

Sawitri, R., \& Iskandar, S. (2012). Keragaman jenis burung di Taman Nasional Kepulauan Wakatobi dan Taman Nasional Kepulauan Seribu. Jurnal Penelitian Hutan dan Konservasi Alam, 9(2), 175-187.

Sofian, N. I. (2018). Lariangi dan Identitas Kaledupa. Jurnal Bastra (Bahasa dan Sastra), 1(1), 113.

Sope, A., \& Kasmiati, S. (2017). Identifikasi Nilai Penting Masjid Agung Bente di Desa Ollo Selatan Kecamatan Kaledupa Kabupaten Wakatobi. Sangia: Journal of Archaeology Research, 1(1), 1-16.

Suni, M., \& Badollahi, M. Z. (2020). Strategi Diversifikasi Atraksi Budaya dalam Mendukung Pengembangan Wisata Desa Wakatobi. Publik (Jurnal Ilmu Administrasi), 9(1), 25-33. 
Suryanegara, E., Suprajaka, \& Nahib, I. (2015). Perubahan Sosial pada Kehidupan Suku Bajo: Studi Kasus di Kepulauan Wakatobi, Sulawesi Tenggara. Majalah Ilmiah Globe, 17(1), 6778.

Suseno, S., Sajiah, A. M., Tarta, A. F., Danial, \& Wahab. (2019). Survei Potensi Kepurbakalaan Gua-Gua di Kecamatan Wiwirano, Kabupaten Konawe Utara melalui Pendekatan Sistem Informasi Geografis (SIG). Sangia: Journal of Archaeology Research, 3(2), 6573.

Suwantoro, G. 2004. Dasar-Dasar Pariwisata. Penerbit Andi, 53.

Syahadat, R. M., Putra, P. T., Saleh, I., Patih, T., Sagala, A. R., \& Thoifur, D. M. (2020). Visual Quality Protection of Ciboer Rice Fields to Maintain the Attraction of Bantar Agung Tourism Village. AGRARIS: Journal of Agribusiness and Rural Development Research, 7(1), 64-77.

Syarifuddin, D. (2018). Nilai Citra Kota dari Sudut Pandang Wisatawan (Studi Tentang Citra Kota Bandung Dampaknya terhadap Kunjungan Ulang). Journal of Indonesian Tourism, Hospitality and Recreation, 1(2), 110.

Tim Ekskursi Wakatobi. (2013). Tanah Airku Air Tanahku Sebuah Rekaman Perjalanan Mahasiswa Arsitektur Universitas Indonesia. Ikatan Mahasiswa Arsitektur FTUI, 4-141.

Tim Infografik Kompas. (2014). Indonesia dalam Infografik. Penerbit Buku Kompas, 20-21.

Tondi, L., \& Ahmad. (2016). Potensi ekonomi wilayah pesisir kabupaten Wakatobi. Jurnal Ekonomi Pembangunan (JEP) UHO, 6(2), $32-42$.

Umar, F. (2018). Strategi Pengembangan Wisata Non-Bahari di Kawasan Waha, Pulau Tomia, Kabupaten Wakatobi. Jurnal Linears, 1(1), $12-19$.

Wakatobi Tourism Authority. (2019). Experiences, Wakatobi A Destination of Thousand. Wakatobi Tourism Authority \& Rumah Kita Wakatobi, 1-139.

Wijaya, A. A. M. (2016). Modal Sosial untuk Kapasitas Community Governance (Studi Kasus Perempuan Pesisir Kelurahan Sulaa Kota Baubau). Jurnal Ilmu Pemerintahan: Kajian Ilmu Pemerintahan dan Politik Daerah, 1(1), 107-125.
World Bank. (2017). Wakatobi Baseline Demand \& Supply, Market Demand Forecasts, and Investment Needs: Market Analysis and Demand Assessments to Support The Development of Integrated Tourism Destinations Across Indonesia. World Bank, 26.

Yayasan Konservasi Alam Nusantara. (2019).. Burung-Burung di Kawasan Mangrove Tampara. Yayasan Konservasi Alam Nusantara, 1-2.

Yulianti, S. D., Adriani, H., \& Syahadat, R. M. (2020). Daya Tarik Wisata di Kebun Raya Cibodas dalam Sudut Pandang Kualitas Visual. Jurnal Lanskap Indonesia, 12(1), 3340.

Yulius, Novianti, N., Arifin, T., Salim, H. L., Ramdhan, M., \& Purbani, D. (2015). Distribusi Spasial Terumbu Karang di Perairan Pulau Wangi-Wangi, Wakatobi. Jurnal Ilmu dan Teknologi Kelautan Tropis, 7(1), 59-69.

Yusiana, L. S., Nurisjah, S., \& Soedharma, D. (2011). Perencanaan Lanskap Wisata Pesisir Berkelanjutan di Teluk Konga, Flores Timur, Nusa Tenggara Timur. Jurnal Lanskap Indonesia, 3(2), 66-72.

Zahari, A. M. (1977). Sejarah dan Adat Fiy Darul Butuni (Buton) I. Proyek Pengembangan Media Kebudayaan Departemen Pendidikan dan Kebudayaan, 91-97. 